\title{
NUMBER OF CONFIRMED CASES OF MENINGITIS IN BRAZIL IN THE PERIOD FROM 2011 TO 2015
}

\section{ORIGINAL ARTICLE}

MATOS, Alex Costa ${ }^{1}$

FECURY, Amanda Alves ${ }^{2}$

OLIVEIRA, Euzébio ${ }^{3}$

DENDASCK, Carla Viana ${ }^{4}$

DIAS, Cláudio Alberto Gellis de Mattos ${ }^{5}$

MATOS, Alex Costa. Et al. Number of confirmed cases of meningitis in Brazil in the period from 2011 to 2015. Revista Científica Multidisciplinar Núcleo do Conhecimento. Year 05, Ed. 05, Vol. 01, pp. 121-130. May 2020. ISSN:2448-0959, Acess link in: https://www.nucleodoconhecimento.com.br/health/meningitis-in-brazil, DOI: 10.32749/nucleodoconhecimento.com.br/health/meningitis-in-brazil

${ }^{1}$ Mining technician by the Institute of Basic, Technical and Technological Education of Amapá (IFAP).

${ }^{2}$ Biomedical, PhD in Topical Diseases, Professor and researcher of the Medicine Course at Campus Macapá, Federal University of Amapá (UNIFAP).

3 Biologist, PhD in Topical Diseases, Professor and researcher of the Physical Education Course at, Federal University of Pará (UFPA).

${ }^{4}$ Theologian, PhD in Psychoanalysis, researcher at the Center for Research and Advanced Studies - CEPA.

${ }^{5}$ Biologist, $\mathrm{PhD}$ in Theory and Research of Behavior, Professor and researcher of the Chemistry Degree Course at the Basic, Technical and Technological Institute of Amapá (IFAP). 


\section{ABSTRACT}

Meningitis is the infection of the meninges that involve the brain and spinal cord, and can be caused by different microorganisms such as bacteria, fungi or acellular organisms (viruses). Bacterial meningitis can have symptoms like fever, stiff neck, nausea, vomiting, photophobia, headache, agitation and seizure. This work aimed to show the number of confirmed cases of Meningitis in Brazil, regarding the year, notification region, age group, sex and race in the period from 2011 to 2015 . The quantitative research was carried out in the DATASUS database[6]. The confirmed cases of meningitis in Brazil in 2015, decreased due to prevention and hygiene campaigns promoted by the federal government, with the help of vaccination campaigns. The Southeast, being the most populous region in Brazil, had a greater number of confirmed cases due to the large concentration of individuals who live in the same environments within society. This causes the disease-causing agent to spread more dynamically. Children and young people were the people most affected by meningitis because they spent a long time in school environments with a large number of individuals.

Keywords: Meningitis, epidemiology, infection.

\section{INTRODUCTION}

The meninges are layers of thin tissue that surround the upper and elongated central nervous system, where the brain and spinal cord are located. (POBB et al., 2013).

Meningitis is the infection of the meninges that involve the brain and spinal cord, and can be caused by different microorganisms such as bacteria, fungi or acellular organisms (viruses) (POBB et al., 2013).

Transmission occurs through prolonged contact with respiratory secretions from infected people (POBB et al., 2013).

Bacterial meningitis can have symptoms such as fever, stiff neck, nausea, vomiting, photophobia, headache, agitation and seizure. (MACHADO e BORGES, 2015). The 
treatment of bacterial meningitis is based on the detection of the type of bacteria that is causing it so that specific antibiotics can be recommended to combat it. (BARCELOS, 2016).

Meningitis caused by viruses can have symptoms similar to bacterial meningitis, such as fever, headache, photophobia, body pain, malaise, altered consciousness, stiff neck and seizures (PELTON, 2010). Viral meningitis has no exclusive treatment because the disease usually subsides within a few weeks. The only recommended treatment is rest and medication for pain and fever (BARCELOS, 2016).

The number of confirmed meningitis cases in Brazil in the period from 2011 to 2015 was approximately 88 thousand cases (MORAIS et al., 2017). In 2013, the country had 18,705 confirmed cases of meningitis, 10,035 in the Southeast, 5,583 in the Northeast, 3,461 in the South, 875 in the Midwest and 751 in the North (RODRIGUES, 2015). In 2014, the North region had 731 confirmed cases of meningitis, with only 15 cases reported in the state of Amapá (DIAS et al., 2017).

\section{AIM}

Show the number of confirmed cases of Meningitis in Brazil, by year, region of notification, age group, sex and race in the period from 2011 to 2015.

\section{METHOD}

Research carried out in the DATASUS database[7]. National data were collected according to the following steps: A) We accessed the link[8], clicked on the "access to information" tab, went to "information system (Tabnet)", "Epidemiological and Morbidity" was clicked. On the open page, there was "Diseases and Notifiable Diseases - From 2007 onwards (SINAN)". On the next page, "meningitis" was selected. In the "geographic scope" box, "Brazil by region, state and municipality" was chosen. From there, the steps to configure the "row", "column" and "content" boxes were followed: A) in the row: "Year 1 symptom (s)" was selected in the column: "not active" and in content: "confirmed cases". For this and all other selections, data from the years 
2011 to 2015 were collected. B) in the line: "Notification region" was selected, in the column: "not active" and in the content: "confirmed cases". C) in line: "Age group" was selected, in the column: "not active" and in the content: "confirmed cases". E) in line: "Year 1 symptom (s)" was selected, in the column: "sex" and in the content: "confirmed cases". F) in line: "Year $1^{\circ}$ symptom (s)" was selected, in the column: "race" and in the content: "confirmed cases". The data was compiled using the Excel application, part of the Microsoft Corporation Office suite. The bibliographic research was carried out in scientific articles, using computers from the computer lab of the Federal Institute of Education, Science and Technology of Amapá, Campus Macapá, located at: Rodovia BR 210 KM 3, s / n - Bairro Brasil Novo . CEP: 68.909-398, Macapá, Amapá, Brazil.

\section{RESULTS}

Figure 1 shows the percentage of confirmed meningitis cases in Brazil between the years 2011 to 2015 . From 2011 to 2012 there was a small increase in the number of cases. From 2013 to 2014 the number of cases decreased. The greatest decrease occurred in 2015 , when compared to the two previous years.

Figure 1 Shows the percentage of confirmed cases of meningitis in Brazil between the years 2011 to 2015 .

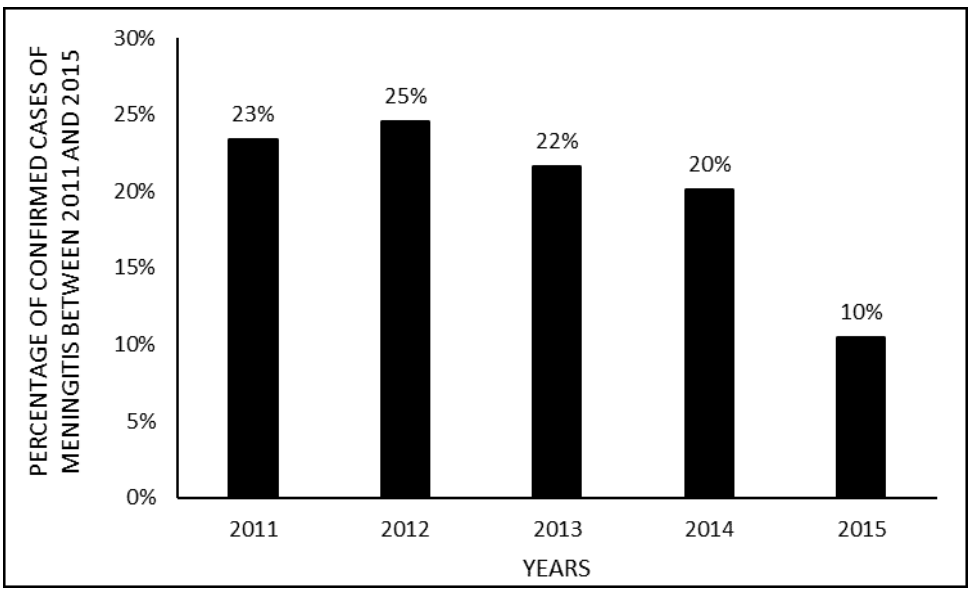

Figure 2 shows the percentage of confirmed cases of meningitis in the regions of Brazil between the years 2011 and 2015 . The southeast region has the largest number of 
cases, followed by the northeast and south regions. The two lowest percentages of confirmed cases occurred respectively in the Midwest and North regions.

Figure 2 Shows the percentage of meningitis cases by region between the years 2011 and 2015.

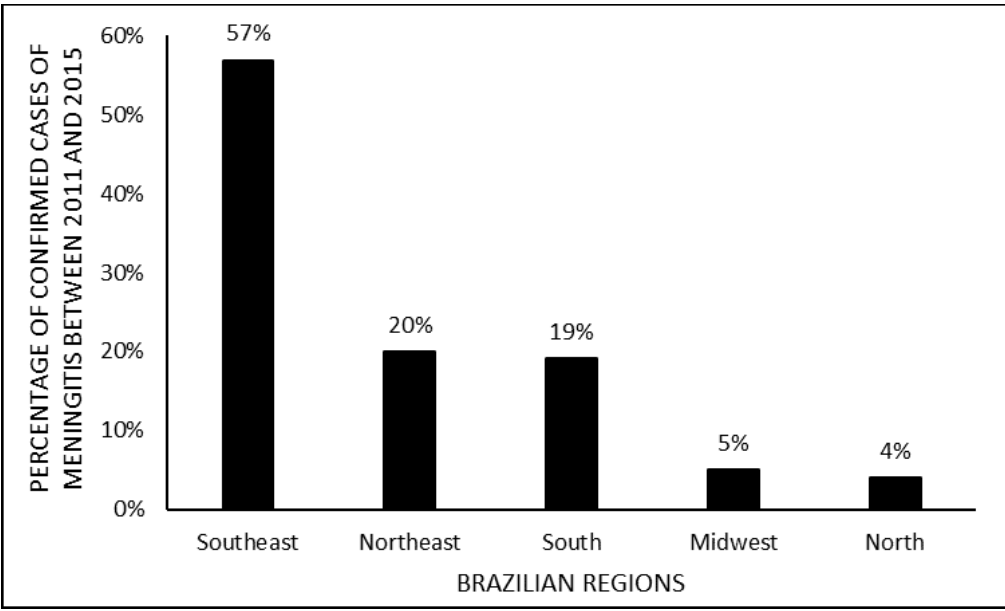

Figure 3 shows the percentage of confirmed cases of meningitis in Brazil by age group (age range), in years, between the years 2011 to 2015. Individuals from 0 to 19 years old have the highest percentage of confirmed cases, followed by individuals from 20 to 39 years old and 40 to 59 years. The age groups with the lowest number of confirmed cases are individuals aged 60 to 79 years and over 80 years, respectively.

Figure 3 Shows the percentage of confirmed meningitis cases by age group (age range), in years, between the years 2011 to 2015 .

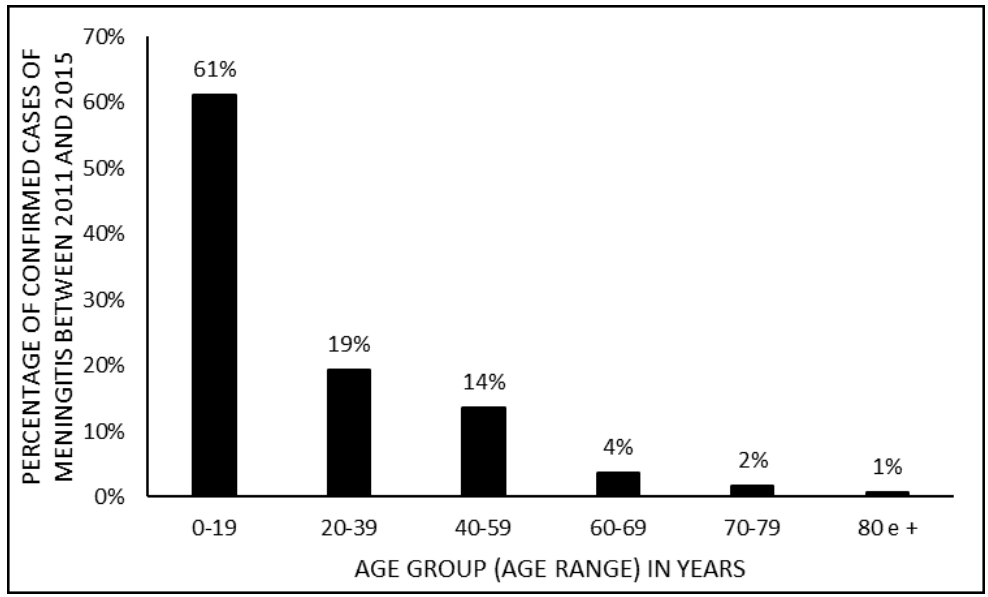


Figure 4 compares the percentage of confirmed cases of meningitis in Brazil by gender between the years 2011 to 2015. In this period, the male gender had a higher average than the female gender. Both maintained a slight fluctuation in the years studied.

Figure 4 Shows a comparison in the percentage of confirmed cases of meningitis by gender between the years 2011 to 2015 .

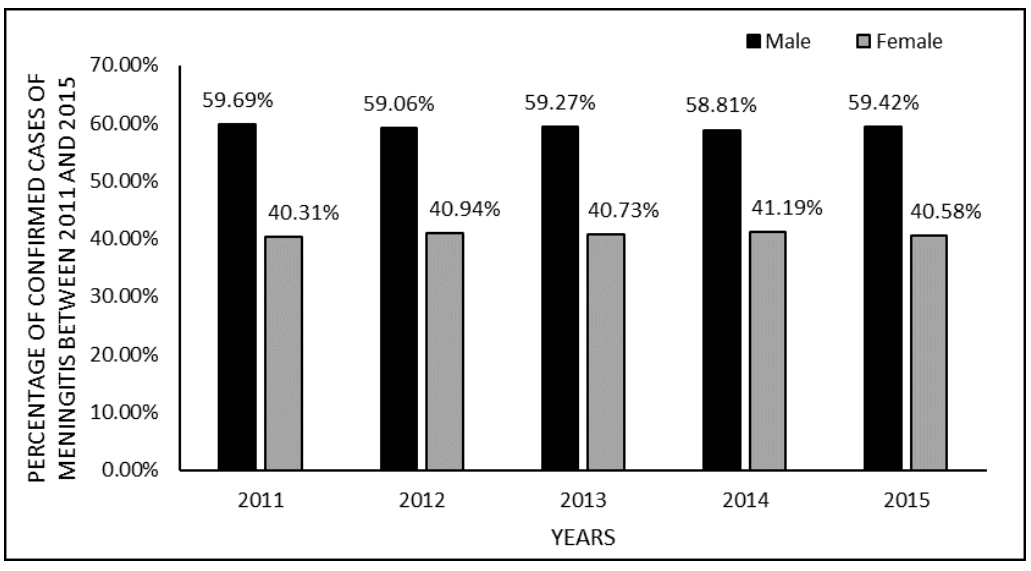

Figure 5 shows the percentage of confirmed cases of meningitis due to Evolution of the disease between 2011 and 2015. We observed that the number of patients discharged is almost nine times higher than those who died from meningitis.

Figure 5 Shows the percentage of confirmed cases of meningitis by race between the years 2011 to 2015 .

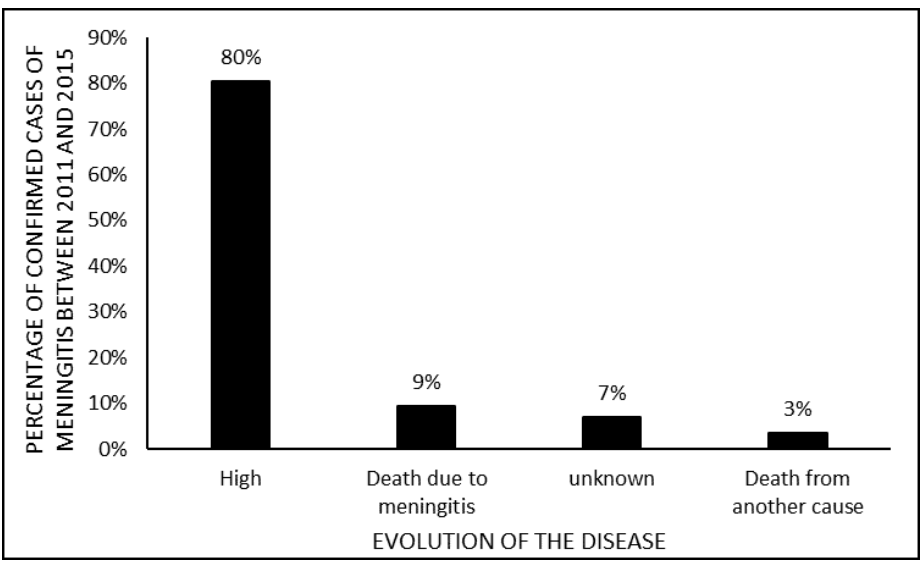

Figure 6 shows the percentage of confirmed cases of meningitis in Brazil by ethnicity (race) between the years 2011 to 2015 . White individuals have the largest number of 
confirmed cases, followed by individuals of mixed ethnicity. The three lowest percentages of confirmed cases appear in individuals of black, yellow and indigenous ethnicity, respectively.

Figure 6 Shows the percentage of confirmed cases of meningitis by race between the years 2011 to 2015 .

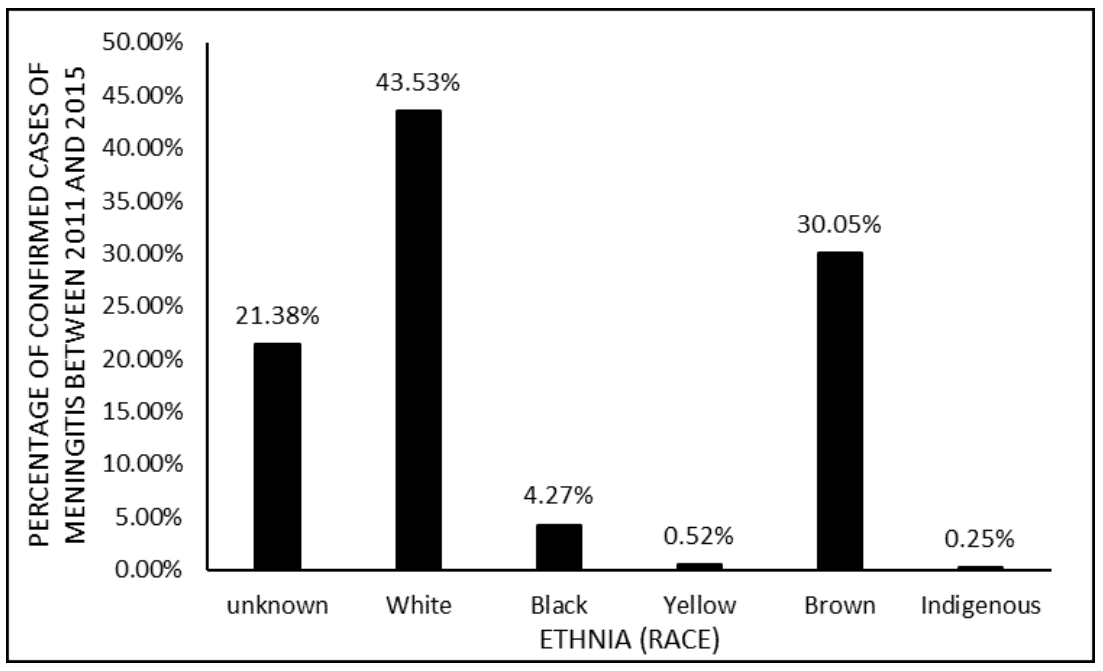

Figure 7 shows the percentage of confirmed meningitis cases by area of residence between the years 2011 to 2015. The urban area has a higher number of infected people while the countryside and periurban areas have extremely low percentages.

Figure 7 Shows the percentage of confirmed cases of meningitis by area of residence between the years 2011 to 2015

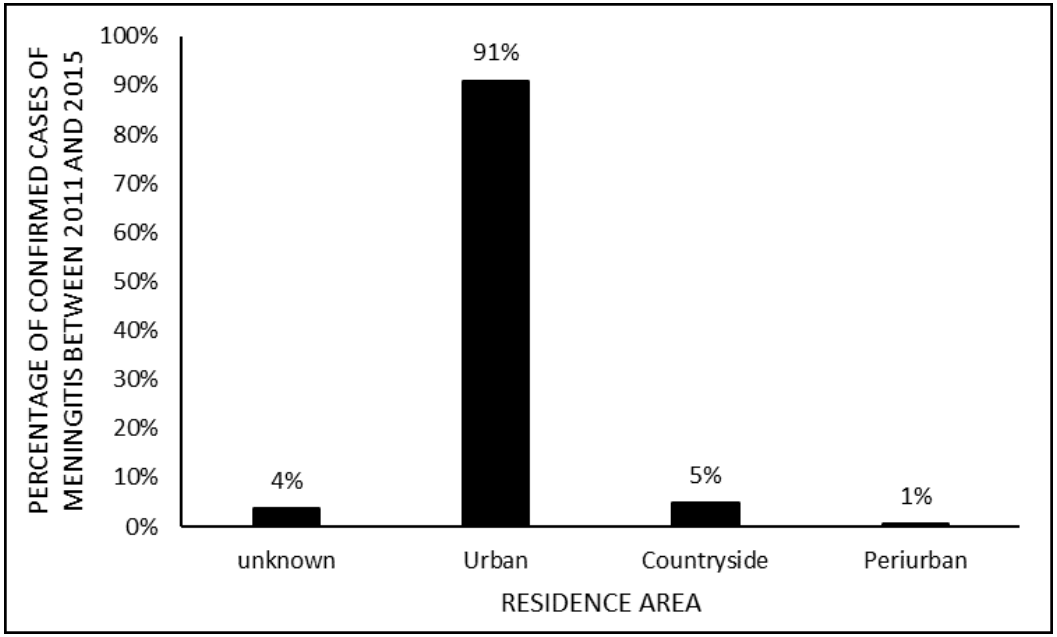

RC: 49749

Disponível em: https://www.nucleodoconhecimento.com.br/health/meningitis-in-brazil 


\section{DISCUSSION}

The data show a stability in the number of cases of meningitis in Brazil in the first four years studied and a decrease in the last year (figure 1). The reduction in the number of confirmed cases of meningitis in 2015 was probably the result of hygiene education and prevention policies promoted by government agencies in each Brazilian state. Vaccination against type B meningitis and BCG vaccine that is applied to the individual after birth has decreased and the number of meningitis cases in Brazil has been decreasing. (GUIMARÃES e MOREIRA, 2014; DIAS et al., 2017).

The southeastern Brazilian region has the highest average of cases of meningitis, followed by the northeastern and southern regions (figure 2). The Southeast region has the largest population in Brazil, followed by the Northeast, South, Midwest and North (IBGE, 2010). The southeast region has a higher number of confirmed cases, probably because it is one of the most developed regions in Brazil and concentrates a large number of individuals. Living in the same area, the population shares the same public transport and working environment. This can cause the disease to spread more quickly, affecting more individuals (RODRIGUES, 2015).

Individuals aged between 0 and 19 years seem to be more affected by meningitis (figure 3). The largest number of confirmed cases in this age group due to factors such as immunological immaturity and the grouping of this population in second and third grade school environments (DIAS et al., 2017).

The data show that the male gender presented more cases of meningitis than the female gender (figure 4). The male gender feels immune to diseases due to their physical size and this makes them seek less the doctor. When they feel symptoms of illnesses, they usually delay going to the doctor, putting themselves at risk and prone to contracting illnesses. (SCHRAIBER et al., 2010).

The research showed that the evolution of meningitis cases is more for cure than for death (figure 5). The development of diagnostic techniques and training of health 
professionals to carry out early treatment of meningitis seems to provide greater success in curing the disease. (RODRIGUES, 2015).

According to the survey, the ethnic group most affected by meningitis was white (figure 6). The data coincide with the literature, however in some cases there are differences that point to the black or brown race having the highest number of confirmed cases, this data conflict is explained by the mix of ethnicities that the Brazilian population presents, and this makes racial determination difficult of the population, since it is selfdeclared (MONTEIRO et al., 2014).

Research shows that the urban area has the highest average of meningitis infected (figure 7). According to the literature, the largest number of cases may be concentrated in the urban area due to the greater number of individuals residing in this region. When taking into account the aerial form of transmission, there is a greater likelihood of contagion in more populated areas (MORAIS et al., 2017).

\section{CONCLUSION}

He confirmed cases of meningitis in Brazil in 2015, decreased due to prevention and hygiene campaigns promoted by the federal government, with the help of vaccination campaigns. The Southeast, being the most populous region in Brazil, had a greater number of confirmed cases due to the large concentration of individuals who live in the same environments within society. This causes the disease-causing agent to spread more dynamically. Children and young people were the people most affected by meningitis because they spent a long time in school environments with a large number of individuals. Men are more affected by meningitis because they are less careful about their health. The immediate diagnosis of meningitis and trained doctors increase the chance of curing infected individuals. Due to difficulties in racial characterization within the Brazilian territory and due to miscegenation there is an alternation between white people with meningitis and black or brown people. The urban area is more affected by having more people residing in this region, which facilitates the transmission of meningitis. 


\section{REFERENCES}

BARCELOS, A. L. M. Ferritina Liquórica no Diagnóstico Etiológico de Meningites em Pediatria. 2016. 62p. (Doutorado). Faculdade de Medicina da PUCRS, Porto Alegre RS.

DIAS, F. C. F. et al. Meningite: Aspectos Epidemiológicos da Doença na Região Norte do Brasil. Revista de Patologia do Tocantins, v. 4, n. 2, p. 46-49, 2017.

GUIMARÃES, I. L. B.; MOREIRA, A. C. A. Perfil epidemiológico da meningite em crianças. RENOME, v. 3, n. 1, p. 1 - 7, 2014.

IBGE. Censo Demográfico 2010. 2010. Disponível em: < http://www.censo2010.ibge.gov.br/sinopse/index/php?uf=29\&dados $=10>$. Acesso em: 14 set. 2017.

MACHADO, C. F. T.; BORGES, B. L. C. Meningite Bacteriana na Unidade de Terapia Intensida; um Protocolo de Cuidados de Enfermegem. UNICIÊNCIAS, v. 19, p. 7985, 2015.

MONTEIRO, L. F. et al. Vigilância clínico-epidemiológica das meningites em um hospital do sul de Santa Catarina, no período entre 2007 a 2013. Arq Catarin Med., v. 43, n. 4, p. 24-29, 2014.

MORAIS, J. M. R. et al. Retrato Da Meningite Em Salvador-BA: Análise do Período entre 2011-2015. Revista Eletrônica da FAINOR, v. 10, n. 1, p. 185-196, 2017.

PELTON, S. I. Meningococcal disease awareness: clinical and epidemiological factors affecting prevention and management in adolescents. Journal of Adolescent Health, v. 46, p. S9-S15, 2010.

POBB, K. et al. Aspectos epidemiológicos e influência de variáveis climáticas nos casos notificados de meningite em crianças no municipio de ponta grossa - PR, 20022011. Revista Brasileira de Climatologia, v. 13, p. 202 - 213, 2013. 
RODRIGUES, E. M. B. Meningite: Perfil Epidemiológico da Doença no Brasil nos Anos de 2007 A 2013. 2015. 16p. (Graduação). UniCEUB

SCHRAIBER, L. B. et al. Necessidades de saúde e masculinidades: atenção primária no cuidado aos homens. Cad. Saúde Pública, v. 26, n. 5, p. 961-970, 2010.

6. http: / /datasus.saude.gov.br/

7. http://datasus.saude.gov.br/

8. datasus.saude.gov.br

Submitted: May, 2020.

Approved: May, 2020. 